\title{
CIDADES DE FOGO E PAIXÃO
}

Wenceslao Machado de Oliveira Júnior

\section{RESUMO}

Estudo sobre o cinema, e a criação do real urbano no cinema, através do espaço e do tempo cinemográficos no filme Fogo e Paixão, de Isay Weinfeld e Marcio Kogan.

\section{PALAVRAS-CHAVE}

Cinema; Cidade; Artes visuais

\section{CITIES OF FIRE AND PASSION}

\section{ABSTRACT}

Study about motion picture, and the creation of the real urban in the movies, through space and cinemographic times in the film Fire and Passion, of Isay Weinfeld and Marcio Kogan.

\section{KEYWORDS}

Motion picture; City; Visual arts 
Um filme cria a fantasia a partir da apropriação que faz da realidade preexistente. Ele a olha diferentemente de nós - a partir de seu olho técnico - e a reconstrói diante de nós, alterando sentidos, criando significados novos.

No cinema, com as cenas movimentadas, pode-se dizer que "o filme circunscreve um espaço de tempo e ilusão em que as categorias mentais que utilizamos em nossa interação com a realidade lá estarão confinadas e transformadas pelos códigos da realidade cinematográfica. É dessa co-fusão que nasce a verossimilhança e sua consequente absorção como realidade, verdade". (Almeida, 1994, p.47).

Este status de verdade foi sendo instituído às imagens em movimento, a tal ponto delas se confundirem com esse real primeiro, ou mesmo negá-lo.

Mas isso não se deve apenas à presença do movimento nas imagens. Xavier escreve que "a falta de interioridade, e sua objetividade de instrumento, é que dá à câmera, ao cinema, a sua revelação da verdade" (1988, p.373). Almeida completa, dizendo que

"esse olhar-real da câmera, quase que indiferenciado, quase que igual ao nosso, é o que vai dar a ilusão de realismo aos signos da realidade projetados na tela do cinema" (1994, p.85).

É, portanto, também devido à pretensa neutralidade da máquina-câmera, e à aparente naturalidade da mesma, que as imagens do cinema se estabelecem como reproduções fiéis da realidade. No entanto, se inicialmente ele, o cinema, se manteve vinculado a esse desejo imperioso de reproduzir o real, logo desvencilhou-se dessa amarra e pôde se lançar às aventuras de criação, inventando um mundo próprio.

A câmera capta o cotidiano - objetos, gestos, etc - e o expõe ante olhos admirados de nunca tê-lo reparado anteriormente. Na tela aparecerão ampliados pequenas coisas, que por serem diminutas, passavam despercebidas por nós.

Pelo fato da câmera ser criadora de ilusões e fantasias ela passa a modificar o nosso olhar. Se o olhar da câmera foi inicialmente, e ainda o é, influenciado pela maneira como os seres humanos observam o mundo e a si mesmos, podemos dizer que, após cem anos de cinema, o olhar da câmera também nos influencia em nossa maneira de ver o mundo, tanto nos ângulos quanto nos sentidos. Olhamos para alguns lugares como se tivéssemos uma câmera no lugar dos olhos!

Numa sociedade onde tudo se acelera e se superficializa, ele, o cinema, reabre-nos a possibilidade dos detalhes. A focalização traz os mais escondidos à mostra. A câmera descobre outros ângulos em nossos espaços de rotina, outros ritmos em nossos tempos corriqueiros.

"Quando a câmera oferece um ponto de vista diferente daquele que temos ordinariamente em relação ao mundo é que ocorre de fato - e somente então - o nascimento da linguagem fílmica propriamente dita." (Martin, p.55)

Ver de tão perto que descobrimos detalhes nunca vistos em objetos de uso pessoal, ver de cima para dar a idéia do conjunto de uma batalha ou de uma cidade, em plongée ou contra-plongée dando um sentido de ampliação ou redução do objeto ou pessoa representado...

No cinema o real pode se tornar mais denso, com uma carga dramática maior, através de tratamentos nas imagens, podendo purificá-las ou intensificá-las.

(c) ETD - Educação Temática Digital , Campinas, v.9, n.1, p.341-360, dez. 2007 - ISSN: 1676-2592. 
O ritmo do cinema é o ritmo do mundo urbano. Um movimento rápido, uma profusão de informações. A negação disto é a negação, pelo diretor, da própria cidade enquanto palco da invenção e do incentivo; neste caso, o ritmo lento já é linguagem, já traz um sentido. Digo que a opção é do diretor porque o cinema é uma arte industrial, já que se realiza a partir da ação conjunta de inúmeros profissionais especializados em suas funções, mas que não conhecem todo o processo de fabricação do filme e, portanto, raramente intervêm decisivamente em sua produção. O diretor no cinema é como o diretor da fábrica (Almeida, 1994, p.31).

No cinema o ritmo e os costumes industriais estão estabelecidos. Produção em série. A reprodutibilidade dos filmes é um imperativo financeiro; as técnicas de produção são caras e variadas exigindo, para que haja ganhos de capital, a sua reprodução seriada (Benjamin, 1985, p.172).

Não só o tempo, ou o ritmo, é uma opção do diretor. No cinema também o espaço é construído para que o filme tenha sentido. No entanto,

"o espaço fílmico não é fundamentalmente diferente do

espaço real, ainda que o cinema nos permita uma

ubiquidade que somos incapazes de realizar na vida normal"

(Martin, 1990, p.201).

Quando nos tornamos câmera, ao nos encontrarmos frente à tela, podemos viajar com ela, estarmos em vários lugares e vermos de vários ângulos um mesmo acontecimento. Atrás da câmera, circulamos como se vivêssemos um sonho, onde a imaginação nos remete para a onipresença. Quando estou na sala escura meus olhos se identificam com a objetiva da câmera e, deste modo, atinjo uma ubiquidade impossível no espaço real: "estou em toda parte e em nenhum lugar (...) sem preencher espaço, sem ter presença reconhecida (...) vejo muito mais e melhor" (Xavier, 1988, p.370).

Não só nossa experimentação do sentido de espaço fica fluída, como também o próprio espaço-conjunto de lugares perde sua rigidez de localização. "A partir de imagens de esquinas, fachadas e avenidas, o cinema cria uma nova geografia" (idem, p. 369), uma outra cidade é mostrada na tela. Os lugares mostrados como pertencentes a uma mesma cidade podem ter sido filmados em cidades muito diferentes e distantes no espaço tradicional. No entanto aparecem próximas no espaço-tempo-cidade do filme.

Ao mesmo tempo não deixam de serem estas as cidades. As imagens mostradas podem ser as do Rio ou de São Paulo, só que não do mesmo jeito que vemos a paisagem destas cidades, os lugares aparecem um após o outro - no tempo - ao invés de um ao lado do outro - no espaço - como acontece tradicionalmente.

Além delas serem apresentadas com um sentido diferente do que elas têm para nós, afinal elas, apesar de serem locais existentes de fato, estão no filme como elemento de sentido e não só como ambientação das cenas.

Portanto o cinema não nos apresenta a cidade, mas o significado dela naquele filme. O faz a partir dos vários fragmentos e tomadas que dela aparecem durante a projeção. Muitas vezes já não será apenas a cidade enquanto espaço social e construído que estará ali presente, mas ela ocupará o lugar de um personagem, um elemento que dá sentido ao filme.

O cinema cria a construção do espaço cujo sentido é temporal, ou seja, os lugares que aparecem como sendo as partes de um espaço maior são mostrados um após o outro - no tempo - numa sequência de tomadas. Raramente a câmera passeia pelo espaço como nós o fazemos, deixando os lugares se encadearam um ao lado do outro no espaço - numa sequência de distâncias e extensões. Essa é, sem dúvida, uma das

(C) ETD - Educação Temática Digital, Campinas, v.9, n.1, p.341-360, dez. 2007 - ISSN: 1676-2592. 


\section{DOSSIÊ}

\section{Área Temática: Educação Visual, Linguagens Visuais e Arte}

mais profundas transformações da noção de espaço: a substituição da contiguidade espacial dos lugares, pela contiguidade temporal na ordenação deles.

Os pedaços urbanos significativos para a trama são condensados e aproximados, pela montagem, na sequência cinematográfica. A montagem da cidade passa a se dar no tempo, quadro a quadro, e não mais no espaço, mapa a mapa.

No filme não há demora. Fecha-se a porta de casa e, na cena seguinte, já se chegou à casa do amigo ou da namorada. Elimina-se o atrito. É o domínio da instantaneidade. O "entre" os lugares deixa de existir. As casas, ruas, monumentos, etc, que estão localizados entre dois lugares, mostrados um após o outro, na tela grande, nenhum espectador é capaz de saber. Portanto, deixa de existir.

Apesar desta total e aparente indiferença à realidade tradicional, as imagens cinematográficas se ligam diretamente a ela. Segundo Couchot elas são imagens da lógica figurativa, ou seja, têm sua morfogênese por projeção, o que "implica sempre a presença de um objeto real preexistente à imagem" (1993, p.39). Neste caso "representar é poder passar de um ponto qualquer de um espaço em três dimensões a seu análogo (seu 'transformador') num espaço de duas dimensões" (idem, p.40).

"A imagem do cinema não é indiferente e por isso é ainda imagem, compreendida como outro, sonho, espelho, fantasia, duplo... No cinema a imagem imagina. O cinema silencia, cria ausência, segredo, suportes para a imaginação... para a relação entre dois. É nesse sentido que o cinema é a última imagem, porque ainda é relação."

(Maciel, 1993, p.254)

O cinema mantém, portanto, uma troca com a cidade filmada. Ele se apossa das coisas urbanas para reproduzir suas imagens, mas abre espaço para que este urbano se esconda, ofereça dificuldades em ser mostrado.

Constituído de fragmentos captados no mundo real, ele - o filme, o cinema - não mostra a realidade, afinal "as técnicas figurativas não são apenas meios para criar imagens de um tipo específico, são também meios de perceber e de interpretar o mundo" (Couchot, 1993, p.41). Há uma invenção, uma remontagem do que foi filmado.

As imagens são colocadas uma após a outra, construindo a ação dramática, dando sentido ao conjunto e a cada um dos fragmentos isolados. Sergei Eisenstein, para quem a montagem era o centro da linguagem cinematográfica, dizia que:

"todo fragmento filmado permanecerá neutro, apesar de fazer parte de uma sequência planejada, até que seja associado a um outro fragmento, quando, de repente, adquire um significado mais intenso e bastante diferente do que o planejado para ele na época da filmagem" (1990, p.20).

A ligação se dá pelo fio condutor do filme: a relação entre os personagens, a recordação de alguém, a correlação entre dois acontecimentos, etc. Na maior parte dos filmes, a ligação entre dois espaços de ação dramática é apenas virtual, não existindo nenhum vínculo com a contiguidade espacial tradicional.

Há uma possibilidade quase que infinita de criação de uma outra cidade pelo cinema. Num único filme, muitas cidades podem ser criadas, visitadas, apresentadas...

$\star \star \star$

No filme Fogo e Paixão, de Isay Weinfeld e Márcio Kogan, a cidade vira delírio,

(c) ETD - Educação Temática Digital , Campinas, v.9, n.1, p.341-360, dez. 2007 - ISSN: 1676-2592. 
DOSSIÊ

Área Temática: Educação Visual, Linguagens Visuais e Arte

brincadeira. Uma colcha de retalhos bem humorada, costurada por uma história inventada por um conde impostor. Paralela ao jogo de conquista ao conde é que aparece a cidade, sempre contraditória, se desmentindo o tempo todo: de uma banca de laranjas se tira uma maçã, em um castelo abandonado vive uma rainha, a Monalisa está fora do quadro e espreita o público, a mendiga e a ricaça se desejam nas vitrines e se repugnam pessoalmente, um piquenique na praça de concreto...
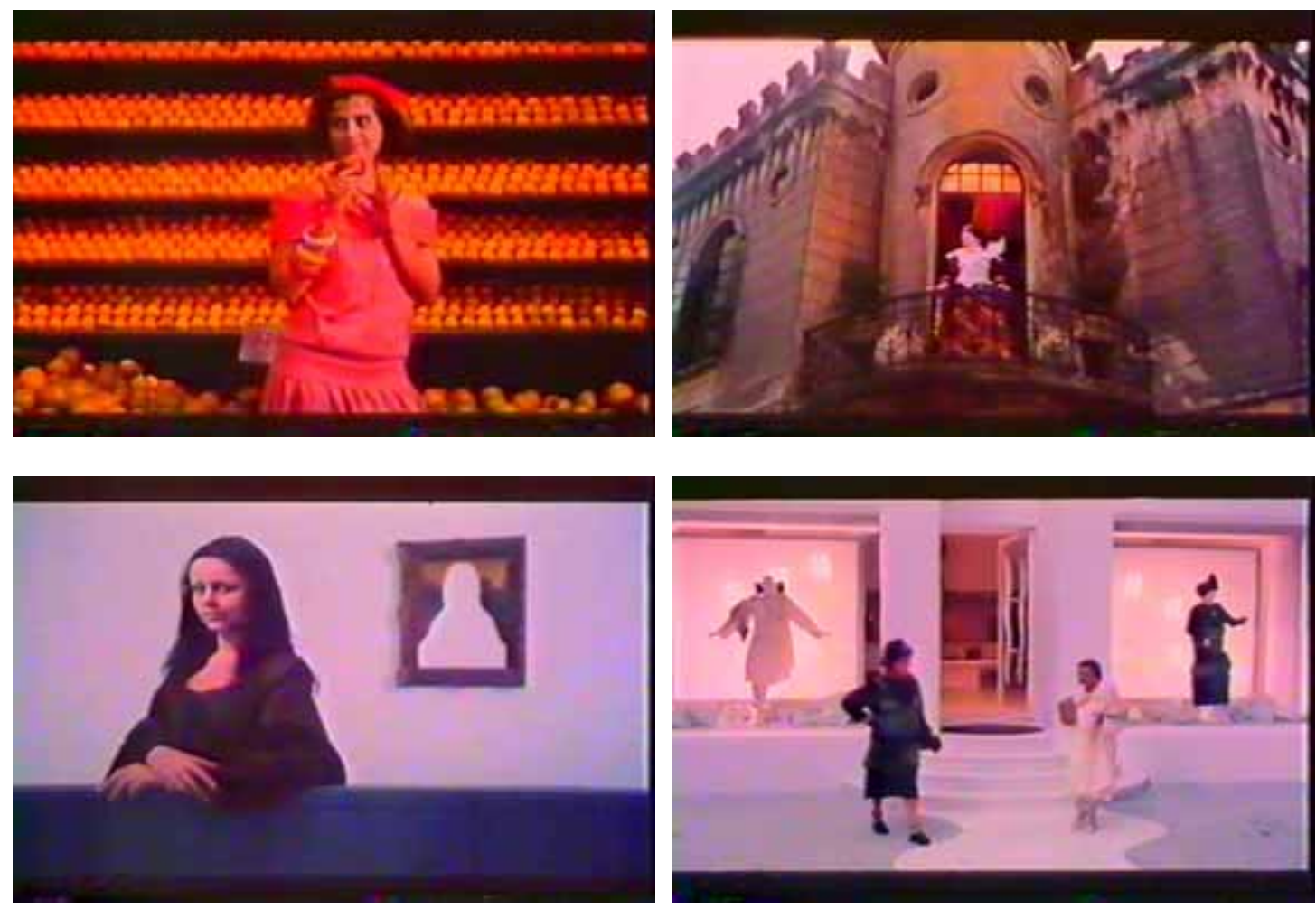

A cidade não se compõe apenas de fragmentos que não se repetem. Há coisas semelhantes por todo canto do espaço urbano, e quem mostra isso é a mulher de rosa que cruza as mais insuspeitadas cenas puxando seu cachorrinho: onipresença do inusitado, repetição em meio à diferenciação.
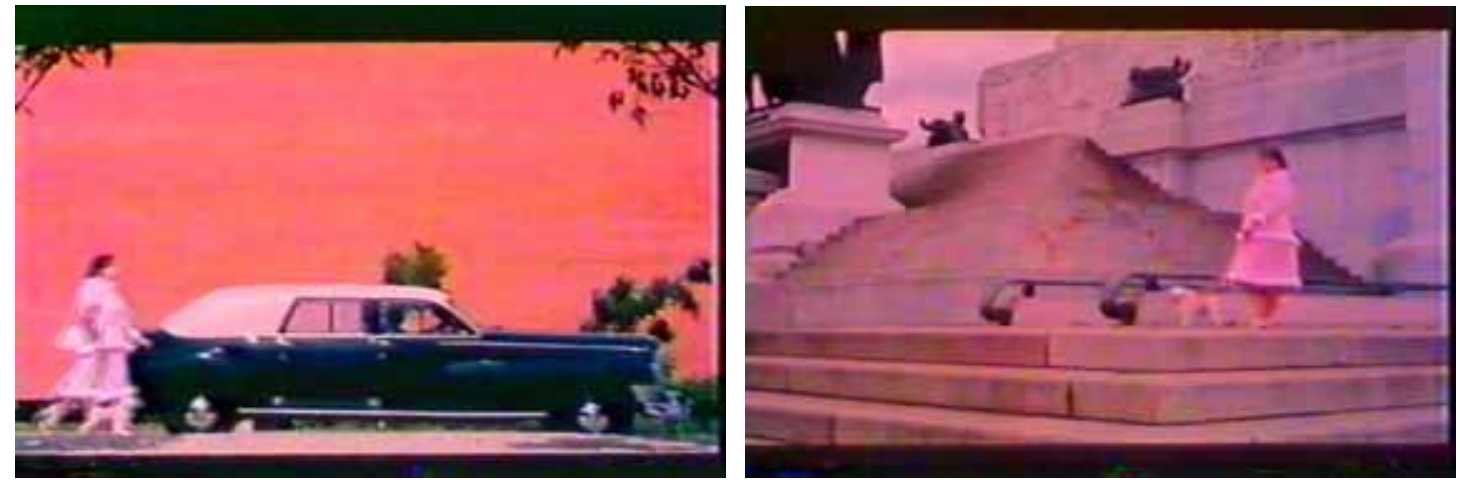

Por fim, ou melhor, já no início, a cidade, a trama, se oferece como enigma, pois é preciso saber japonês para decifrar o final da história.

(C) ETD - Educação Temática Digital, Campinas, v.9, n.1, p.341-360, dez. 2007 - ISSN: 1676-2592. 
O filme vai sendo construído por contrastes e pelo sem sentido. Ele é mostrado como montagem, como brincadeira. Para que o carro do conde possa estacionar, o motorista retira do chão as faixas de pedestre...

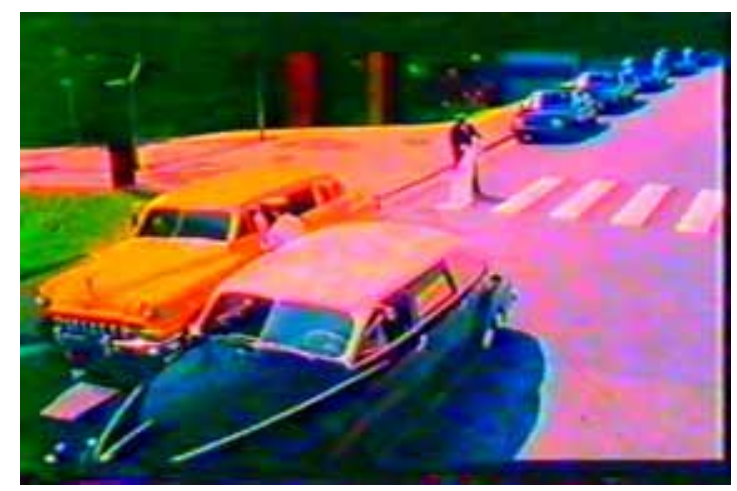

Este filme lida com o óbvio. Não tem pretensões de ser um momento de reflexão profunda sobre os homens ou sobre algum deles. Tem o objetivo de nos divertir com o reconhecimento de nossas vidas num daqueles personagens que só não se tornam trágicos dadas às circunstâncias cômicas em que são postos na trama.

O filme é para rir das muitas ilusões desvendadas pelo distanciamento da câmera ou pela mudança de ângulo na filmagem: pele de onça mostra-se casaco feminino, piscina mostra-se sem água, carrinho de bebê mostra-se com compras de feira...

Mas não só o riso solto e descompromissado da comédia nos é suscitado, mas também um riso meio nervoso, como se ríssemos de nós mesmos, de nossas contradições, de nossas desigualdades, de nossas identidades, do nosso sem sentido.

Do mesmo modo que estas duas maneiras de rir perpassam o filme, são duas as cidades que se cruzam em Fogo e Paixão. Uma para ser vista e outra que está sendo vivida ali, e, no entanto, elas não se vêem, não se comunicam, não falam a mesma língua. Uma não se importa com a outra.

Uma delas, a cidade apresentada aos turistas estrangeiros, é aquela dos pontos importantes para o poder oficial, dos museus e monumentos estabelecidos como marcos de nossa arte e história. Uma cidade para inglês ver. É o discurso daqueles que se beneficiam da cidade fazem, um discurso certamente belo. É a cidade de pedra e cimento. Nela os lugares aparecem onde pára o ônibus.
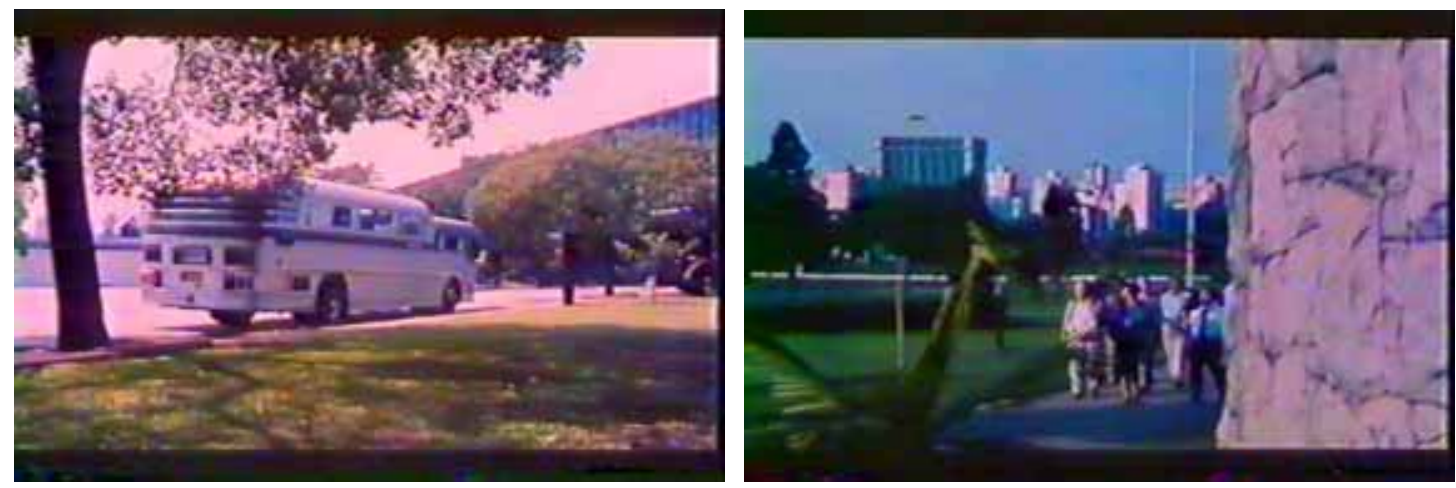

(C) ETD - Educação Temática Digital , Campinas, v.9, n.1, p.341-360, dez. 2007 - ISSN: 1676-2592. 
Área Temática: Educação Visual, Linguagens Visuais e Arte
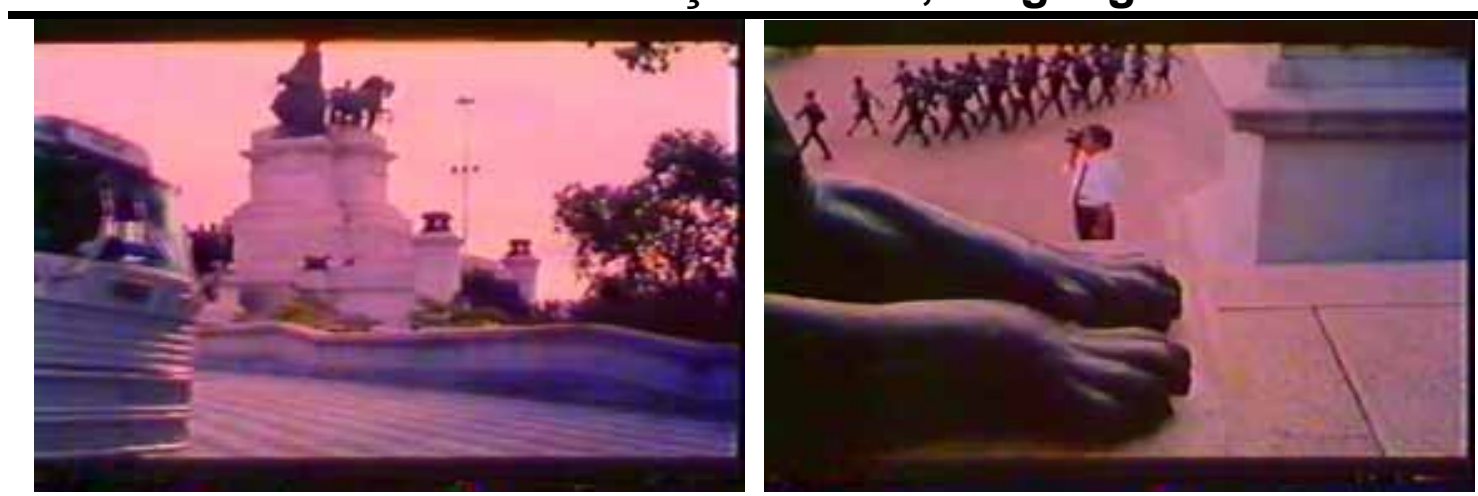

Entre estes lugares há apenas elevados e cruzamentos sem nada ao largo. Entre eles o ônibus circula numa espécie de vazio urbano, visto que nada por onde ele passa têm sentido no discurso que o turismo faz da cidade. Nestes momentos a cidade é mero deslocamento.
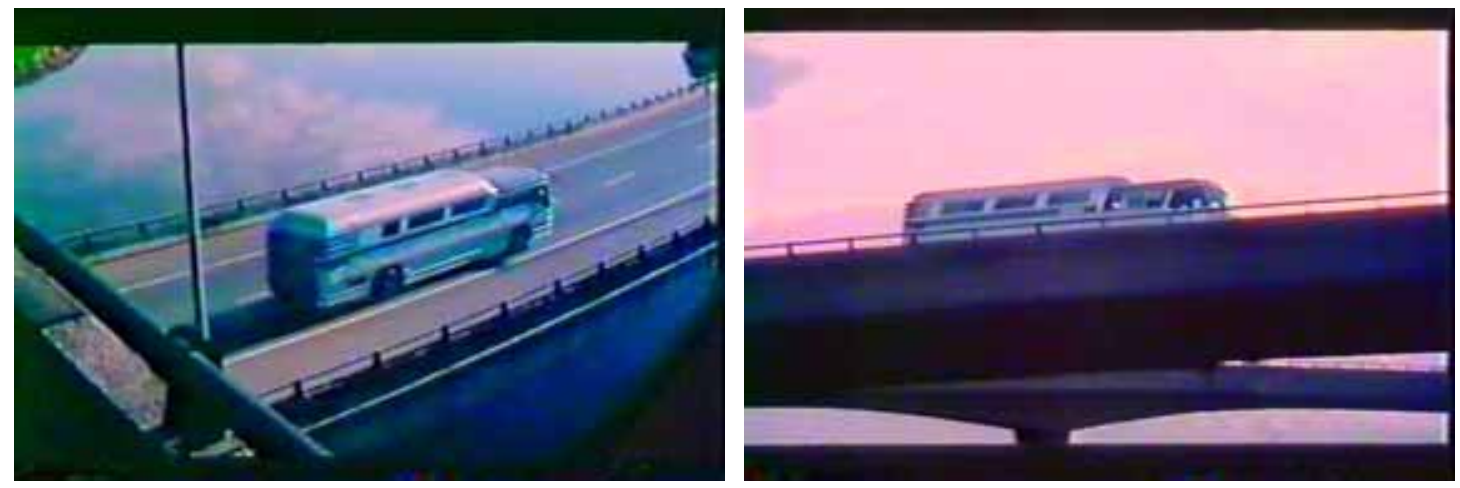

É o turismo, com sua origem burguesa em meados do século XIX, que, num primeiro momento, começou a direcionar os nossos olhos. Olhar especificamente algumas coisas numa cidade - quando a visitamos ou nela chegamos pela primeira vez criando marcos referenciais que virão a situar este espaço urbano em nossas memórias.

Com tudo o que lhe é peculiar e característico, esse tipo de viagem, com seus guias e roteiros... depois cartões postais e fotografias... e finalmente filmagens..., estabeleceu as primeiras "focalizações em massa" nas cidades. Aquilo que era para ser visto e aquilo que deveria ser negligenciado não mais está a cargo do indivíduo ou grupo, mas do agente de viagens. Os lugares belos, pitorescos ou singulares são salientados, pinçados da massa urbana envolvente e, pelo menos para os turistas, tornam-se a cidade.

Não serão mais elementos vinculados à história de vida e ao processo de experimentação do espaço que identificarão uma cidade, mas o que nos foi mostrado por outra pessoa.

Os agentes de turismo sempre agiram como padronizadores da cidade, redutores dela aos lugares turísticos. Primeiramente a indústria do turismo explorou as belezas dos lugares - praias, monumentos, igrejas, vistas panorâmicas, etc - depois suas feiúras ruínas, miséria, etc - tendo sempre o pitoresco como norma. E é este pitoresco que tem se expandido de importância desde então. Por ser o único que é mostrado, é o único que é visto, que se destaca na memória, que se torna a única lembrança. No filme, a agente de viagem anuncia os lugares por onde o ônibus passa e onde o ônibus pára, além de indicar aos passageiros o que olhar e por onde passar. 


\section{DOSSIÊ}

\section{Área Temática: Educação Visual, Linguagens Visuais e Arte}
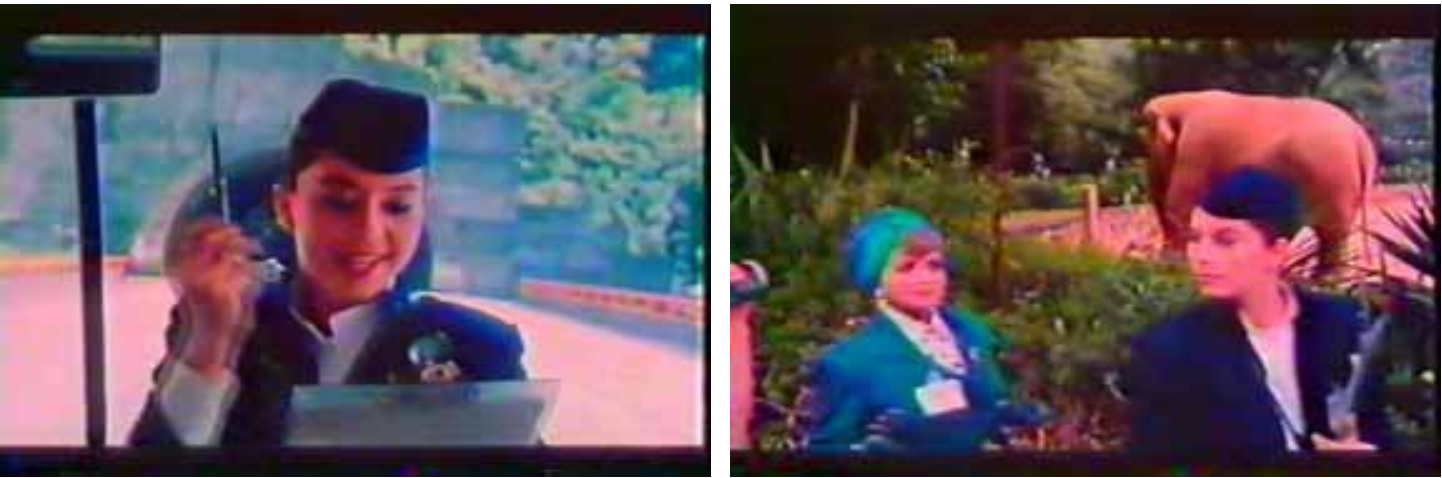

Antes mesmo do turismo, eram as singularidades dos lugares que os marcavam, que os tornavam memoráveis aos viajantes. No entanto, elas estavam pelo menos embebidas pela cidade ao seu redor, pois aquilo que chamava a atenção de um viajante nem sempre era o mesmo que despertava o olhar de outros. Eram as experiências individuais que determinavam as lembranças. Isto proporcionava muitas variadas recordações e marcas de um mesmo lugar. Cada um escolhia o que lhe era marcante ou pitoresco o suficiente para que guardasse na memória.

Com isto não quero dizer que as recordações dos lugares eram sempre muito diferentes e com poucos elementos comuns. O morro do Pão de Açúcar no Rio de Janeiro, certamente foi uma lembrança para quase todos os que por ali passaram, mesmo que ninguém tenha lhes chamado atenção para sua forma. Ele é um elemento por demais marcante na paisagem para que passe despercebido.

O direcionamento do olhar proposto pelos agentes de turismo, e acatado pelo turista, termina por homogeneizar o que é visto, gerando uma memória coletiva muito mais massificada que antes, e que vai ser aproveitada e aperfeiçoada pela televisão. Esta vai nos oferecer uma espécie de turismo televisivo, com preocupação exclusiva de garantir uma outra necessidade: manter o telespectador preso à tela.

O turista está de passagem, ficará pouco tempo, e por isso não espera que a cidade se ofereça aos poucos ao seu olhar; ele tem gula de conhecê-la. Observa a paisagem e a vida urbana em busca de referenciais para sua memória, que o lembrará de lugares não mais presentes quando voltar para casa. Busca, portanto, marcos especiais que o façam lembrar.

O morador observa a cidade, encontrando nela referenciais para vivê-la no dia-adia. Ela é, por ele, apropriada aos poucos. Seus elementos que se destacam estão vinculados ao uso que cada morador faz dela, na localização dos lugares e nos deslocamentos. Os elementos presentes nas imagens que o morador faz de sua cidade são muitos, pois múltiplas são nossas atividades dentro do espaço urbanizado em que vivemos. Eles variam de acordo com a idade, o sexo ou profissão do habitante, já que serão diferentes os usos que se farão da cidade em cada um desses grupos.

A cidade vivida pelos brasileiros, pelos que falam a mesma língua dela, é outra: dos problemas sociais, da solidão, das desilusões amorosas, do sexo, do casamento, das tradições e das contradições que, no limite, construíram a cidade oficial.

A primeira, do turista, é uma cidade emblema, feita de coisas, objetos e histórias. A última, do morador, é feita de homens, mulheres e suas relações de poder, das mais particularizadas às mais genéricas, das que envolvem o sexo e o amor a dois às que

(C) ETD - Educação Temática Digital , Campinas, v.9, n.1, p.341-360, dez. 2007 - ISSN: 1676-2592. 
envolvem as trocas políticas e econômicas dos grupos sociais. São elas que se cruzam neste filme, quase sem se tocar...

Há uma penetração significativa da linguagem do vídeo neste filme.

Ele é montado como um amontoado, aparentemente aleatórios, de clips variados, colocados em sequência tanto temporal quanto espacial. Os olhos do espectador percebem quadro a quadro os personagens e os lugares daquela cidade exposta na tela. Os olhos e os pés dos personagens percorrem os vários lugares daquilo que aos poucos vai tornando-se o ambiente daquele dia.

Cada clip tem uma só mensagem que é dada rapidamente, é como um pedaço comprimido que representa o todo, uma maneira de enriquecer algo mais simples. A Monalisa debruçada na escada, fora do quadro ao fundo enquanto os excursionistas passam, é um bom exemplo disto.

A própria construção do quadro cinematográfico é aproximada à construção do quadro televisivo: estilizado, limpo, contendo poucos detalhes, buscando uma significação mais direta e unificada.

Quem assiste ao vídeo são personagens de Walt Disney: Patetas, Donalds e Mickeys que estão por trás da porta de vidro que se abre ao começar o filme.
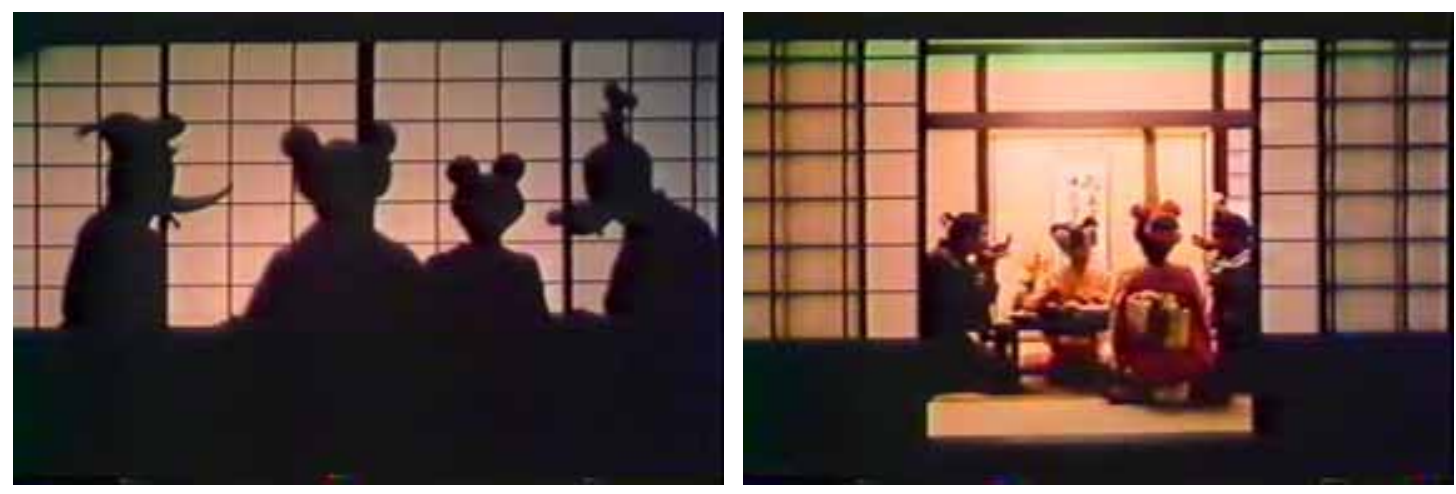

É o vídeo e a televisão dentro do cinema, é um filme dentro do outro. Um japonês vendo e filmando os homens e mulheres brasileiros e os outros estrangeiros que vieram visitar aquela cidade. Ser híbrido, este japonês da câmera é, ao mesmo tempo, personagem e diretor do filme.

É a câmera dele que capta muitas das cenas. São dele as várias cenas em que alguns personagens são mostrados sozinhos tendo um detalhe da cidade como fundo. A "paisagem objetiva" que está por trás do vidro do ônibus em cada uma destas cenas está claramente mostrando o "estado interior" de cada personagem. 
DOSSIÊ

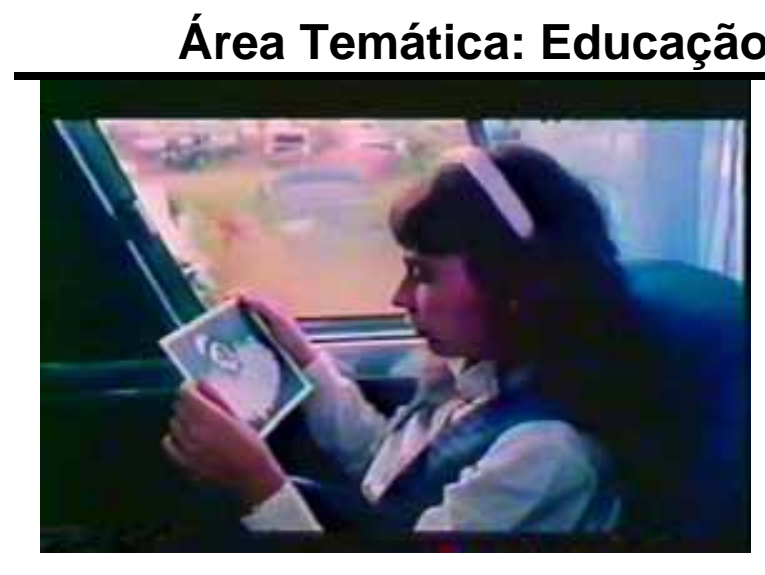

Visual, Linguagens Visuais e Arte
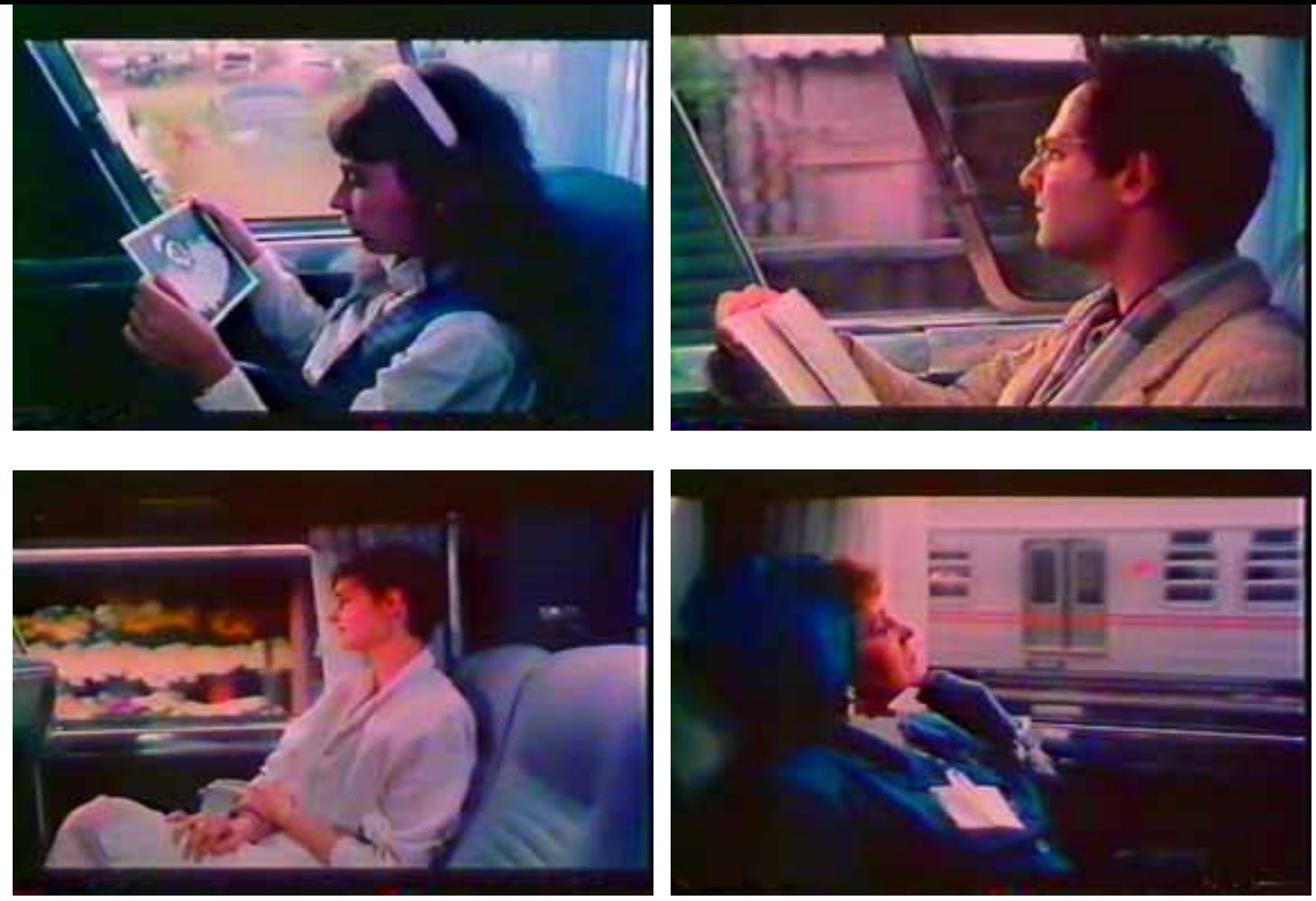

Ao apresentar o interno dos homens através de coisas participantes de uma realidade externa a eles, o diretor torna o cinema um meio que aponta para o que Fernando Pessoa escreve como sendo a forma humana de experimentação da realidade cotidiana:

"Em todo o momento de atividade mental acontece em nós um duplo fenômeno de percepção: ao mesmo tempo que temos consciência dum estado de alma, temos diante de nós, impressionando-nos os sentidos que estão virados para o exterior, uma paisagem qualquer, entendendo por paisagem (...) tudo o que forma o mundo exterior num dado momento da nossa percepção.

Todo estado de alma é uma paisagem. (...) Há em nós um espaço interior onde a matéria da nossa vida física se agita. Assim uma tristeza é um lago morto dentro de nós, uma alegria um dia de sol no nosso espírito. (...)

Essas paisagens fundem-se, interpenetram-se, de modo que o nosso estado de alma (...) sofre um pouco da paisagem que estamos vendo (...) e, também, a paisagem exterior sofre do nosso estado de alma. (...) De maneira que a arte que queira representar bem a realidade terá de a dar através duma representação simultânea da paisagem interior e da paisagem exterior (...)". (p.73-4)

O que poderia significar um ferro-velho ou túmulos ao fundo de uma garota sozinha e com olhar distante? O que quereria dizer o diretor com as flores que aparecem ao fundo quando a jovem francesinha sonha? Ou com a favela para o leitor de Igreja, carisma $e$ poder? Ou ainda com a central de transformação e distribuição de energia elétrica que

(C) ETD - Educação Temática Digital , Campinas, v.9, n.1, p.341-360, dez. 2007 - ISSN: 1676-2592. 350 


\section{DOSSIÊ}

\section{Área Temática: Educação Visual, Linguagens Visuais e Arte}

está por trás de Wilma e Helena? Acredito que os significados sejam diretos nestas cenas, ao contrário do que ocorrerá quando um trem do subúrbio aparece ao largo do ônibus quando a aristocrata russa é filmada. A inquietude dela nos dá a impressão de ser causada pela contradição existente entre o que se passa em seu rico interior e o que ocorre no mundo ao seu redor. filme.

Falemos um pouco dos personagens que compuseram uma das cidades deste

Helena e Wilma, que retratam a solidão feminina, bem como o embate e a contradição entre os tradicionais ideais de casamento e a vida que se tem na grande cidade, têm, cada uma a sua peculiaridade. Helena, a polidez formal do moderno e Wilma, o bom humor do senso comum tradicional. Todas duas misturam elementos tradicionais e modernos, mas há mais aproximação com o mundo urbano e moderno na primeira, suas roupas espelham uma incorporação maior da urbanidade, principalmente quando ela resolve conquistar o conde, pois tira o lenço que lhe cobria o colo e rasga o vestido, deixando grande parte de sua perna à mostra.

O conde é o príncipe encantado procurado tanto pela tradicionalidade de Wilma quanto pela modernidade de Helena. A dúvida que ele passa a ter entre elas é entre a harmônica e a fala solta e comum da última e o inglês e a sensualidade da primeira?!!

Estes são os personagens centrais do filme e tudo gira em torno deles e de Gaspar, um solteiro operador da bolsa de valores com seus 40 anos que adora tudo aquilo que se relaciona à família.

Portanto, o eixo desta cidade humana e relacional é a paquera, a conquista, o sonho. Mas também a indecisão, a concorrência.

Os outros personagens são secundários: o motorista que ouve ópera, a guia que está mais preocupada com o inspetor, a jovem francesa que só fala merd, o casal americano para o qual tudo é beautiful, a aristocrata russa, a garota solitária, o ativista de esquerda, o japonês que tudo filma, o português que segura uma misteriosa maleta, o homem de preto que entra na excursão quase no final do filme e a mulher com suas muitas filhas e sua mãe que só diz é. As histórias e imaginações de cada um não se estabelecem em relação a outro personagem, mas em relação à cidade. $E$ são curtas: aparecem uma só vez.

Outros inúmeros personagens terão lugar no filme, mas não farão parte dos que estão dentro do ônibus, mas da cidade lá fora: o político populista e puxa-saco do padre e sua mulher que é amante do militar, o taxista, o motorista do conde, a mendiga e a milionária, a monalisa desenquadrada, a rainha caolha, o casal que faz piquenique, o carlitos do museu, a menina da banca de laranjas e o velho da maleta, além de outros de que não me recordo. São tantos seres incomuns que nos esquecemos de alguns deles.

Há uma personagem que aparece e desaparece, aliás que passa pelo filme, pela cidade. Ela liga sonhos, realidades, personagens de dentro e de fora do ônibus. É a mulher gorda e de vestido rosa que anda com seu cachorrinho a latir pela cidade afora. É ela, em certo sentido, que faz da cidade algo único, igual apesar de diferente. Ela é o homem comum, um conceito, que passa por nós em qualquer lugar de nossas perambulações urbanas. No entanto, essa personagem não tem nada de comum, apontando o quanto de não comum tem cada um daqueles que chamamos homens e mulheres comuns e, com isso, não reparamos neles e nelas.

O olhar de perto traz as pessoas com seus mais íntimos sentimentos e desejos. As cenas do piquenique no campo e da rainha em sua pompa mergulham na intimidade de

(C) ETD - Educação Temática Digital , Campinas, v.9, n.1, p.341-360, dez. 2007 - ISSN: 1676-2592. 


\section{DOSSIÊ}

\section{Área Temática: Educação Visual, Linguagens Visuais e Arte}

certos cidadãos urbanos e nos expõem seus "sonhos dourados". Nos primeiros segundos das cenas já estamos diante de personagens contraditórios com a cidade que conhecemos ou com aquela que vem sendo mostrada pelas demais imagens do filme. Estas cenas quebram o visual urbano e moderno trazendo a nós outros espaços e tempos, outras formas de poder e glória não mais presentes em nosso cotidiano urbano. Propõem um entendimento - um riso - da cidade por corte, por rompimento, ou, no limite, por comparação.

Estas cenas são calmas, aparecem como a embalar aqueles que por ventura cochilem nos bancos do ônibus.

A primeira delas se inicia com a maior proximidade possível para o reconhecimento do fato encenado: um casal faz um piquenique sobre um gramado muito verde. Confirmando as imagens que estão sendo vistas, há sons de pássaros e mugidos do gado, de galo cantando, de água correndo, de grilos e folhas secas.
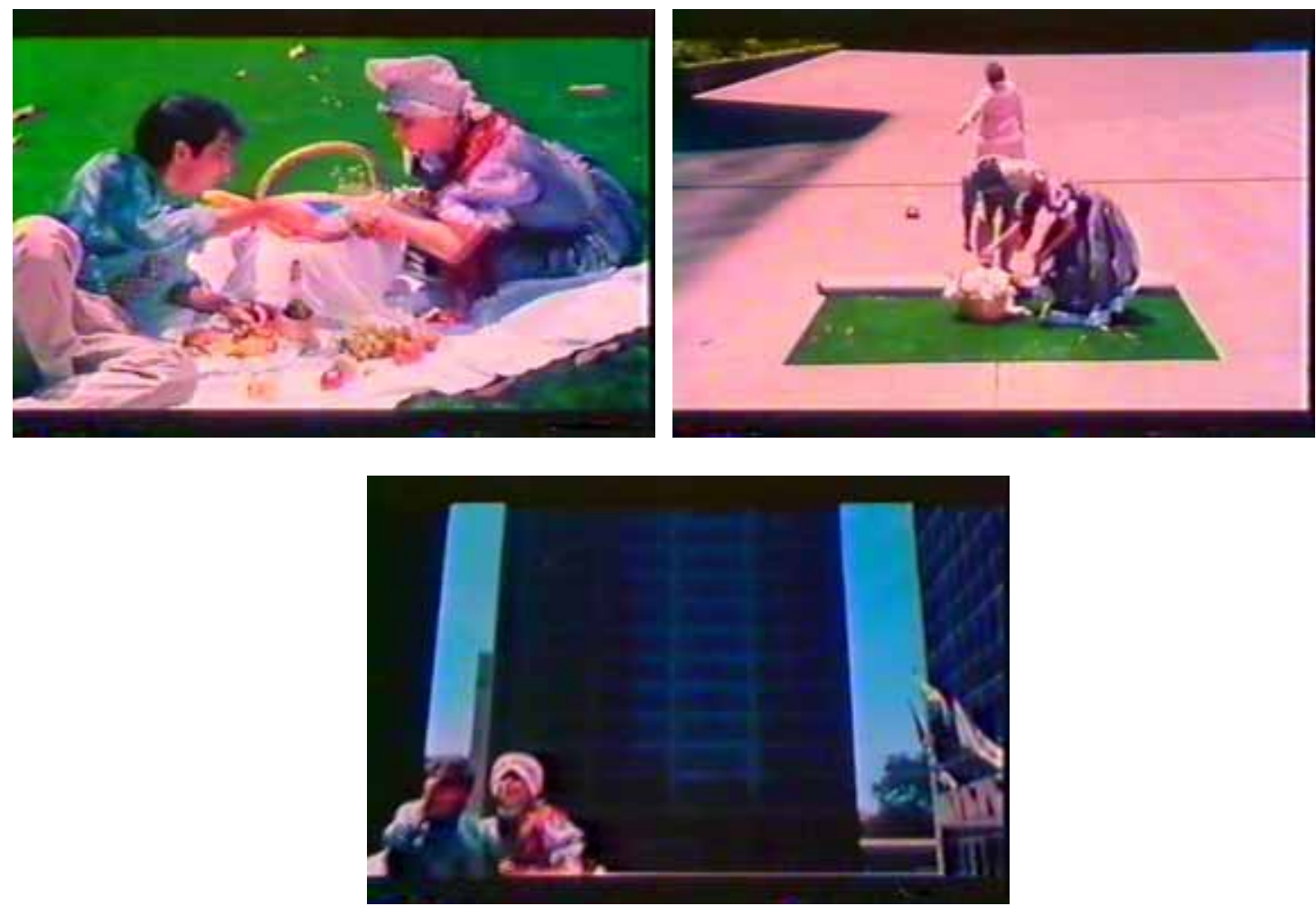

Ao mesmo tempo que a câmera começa a descrever um percurso de zoom out, ampliando os horizontes visíveis ao espectador, os sons tipicamente urbanos começam a aparecer: buzinas e latidos de cães antecipam o aparecimento dos imensos prédios que cercam o local do piquenique e que finalizarão a cena, após o casal ter enrolado o tapete verde e guardado a cesta de frutas e pães, bem como a toalha xadrez. Uma vez tirado o tapete aparece o concreto que subjazia à cena.

A segunda cena se inicia com uma tomada em contra-plongée de uma construção que se assemelha a um castelo, com suas torres e sacadas. À medida que a câmera se aproxima da sacada uma porta vai-se abrindo lentamente e vemos surgir uma rainha caolha. 


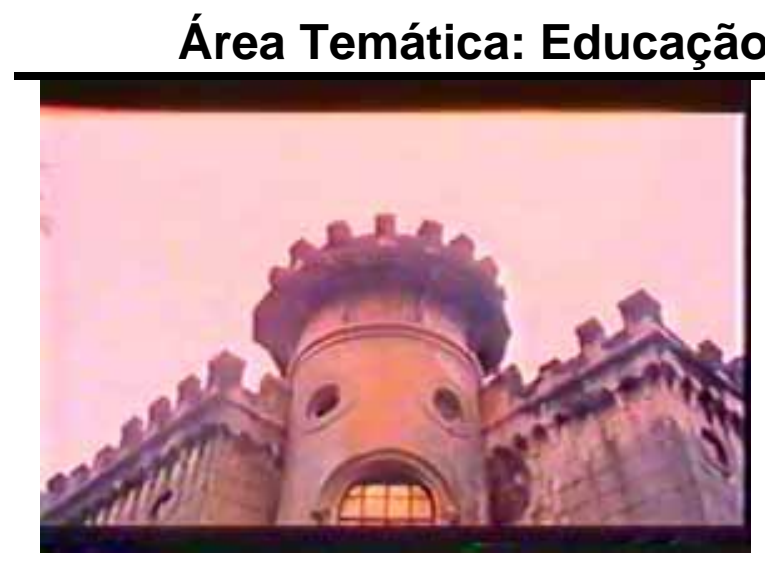

Visual, Linguagens Visuais e Arte

Ela sai à sacada com um olhar altivo, como que admirada por milhares de súditos. A música que se ouve nos remete para um tempo mais antigo. Aos poucos a câmera começa a se elevar, dando uma visão mais ampla, situando este castelo em seu entorno urbano.

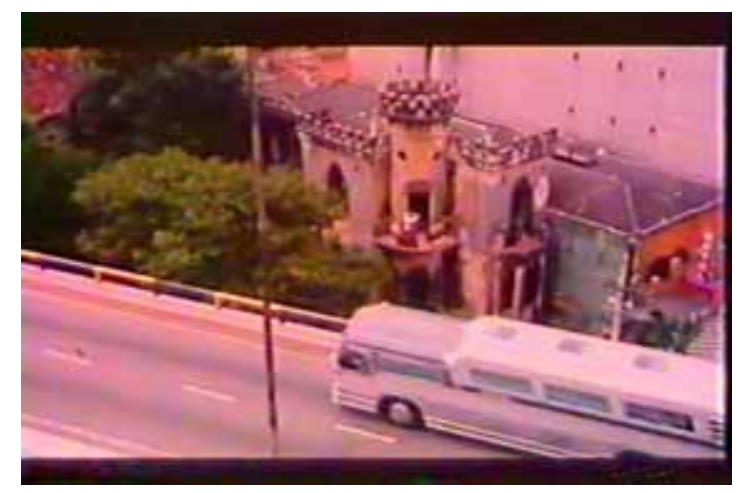

Antecipando a decrepitude do velho castelinho são ouvidos sons como que de pássaros a gritar e o barulho do ônibus com os personagens principais da trama do filme. O ônibus e o elevado por onde passa são captados pela câmera no alto e nos carrega de volta à grande cidade e à sociedade que vai corrompendo e destruindo os sonhos mais íntimos e os colocando frente a uma realidade inexoralvelmente diversa deles.

Posso arriscar dizer que o olhar mais amplo, que vai incorporando outros horizontes urbanos - tanto na primeira como na segunda das cenas descritas acima -, é que torna estas intimidades visíveis, pois que trágicas, interrompidas, pois que são mais um elemento deste espelho estilhaçado que é a cidade moderna. Há um rompimento cruel entre alguns homens e a cidade em que vivem. Os edifícios cercaram o piquenique, os sons urbanos invadiram tudo e nenhuma intimidade é possível sem o head-phone e o walk-man.

Os sons que são ouvidos no filme são elementos importantes de significado. Os sons tornaram as imagens mais afetivas e envolventes, mais próximas do espectador, criando um momento de intensidade maior que a maioria dos momentos cotidianos. $O$ que é visto e ouvido na tela terá, a partir de então, marcas mais fortes em nossa memória. A sincronia deles com as imagens é que cria o sentido do momento apresentado no cinema.

Imagens e sons não necessariamente se confirmam. Nas cenas descritas logo acima, câmeras e microfones vão deixando aos poucos e sincronizadamente o interior sonhador dos personagens para ir mergulhando devagarinho em seu personagem maior: 
DOSSIÊ

Área Temática: Educação Visual, Linguagens Visuais e Arte

a cidade com seus ruídos, formas e materiais característicos. A trilha sonora urbana é descontínua no tempo, nos intervalos, nos lugares, nas intensidades. Ela é arbitrária ${ }^{1}$.

Uma das atividades que o diretor do filme faz, ao filmar coisas reais em cidades reais é eliminar os sons ambientes e colocar outros, dando a ele - diretor - e às coisas filmadas - ambientes - outras possibilidades de sentido. Neste caso, ao entrarmos no filme Fogo e Paixão é como se cada um dos espectadores ganhasse um fone de ouvido e um toca-fitas portátil com os mesmos sons gravados numa mesma sequência. Ao querer dar à cidade, ou a partes dela, outros sentidos que não os cotidianos, o diretor muitas vezes manipula os sons e não as imagens. Ele rompe com os sons do entorno do lugar filmado e impõe outros, que dão outro sentido àquele lugar.

Também as imagens devem ser selecionadas para o filme. Quando o cenário do filme é o real, o trabalho do diretor e sua equipe é de estabelecer cortes, ângulos, perspectivas que, por um lado aprofundem o - sentido do - lugar-coisa desejada e, por outro, eliminem o entorno que redefiniria o olhar do espectador e portanto, o sentido do lugar-objeto filmado.

Quando o lugar onde se passa a cena é um lugar real, existente anteriormente ao filme, é tão importante o que foi incluído quanto o que foi excluído da tela. Principalmente quando este lugar-cenário é parte de um espaço urbano isto se faz notar.

A cidade, o urbano constituído, é uma narrativa não linear, ou não unicamente linear. Ela permite tantas entradas e saídas de significado, tantos mergulhos quantas perspectivas se têm no olhar. E elas são infinitas, dada não só a infinidade de coisas a serem observadas em suas mais que diversas relações, mas também e principalmente porque na cidade estamos em constante movimento e, consequentemente em constante mudança de rumo e perspectiva de olhar. Enfim, na cidade estamos vivos e independentes, o olhar está solto, nós é que o enclausuramos e o obrigamos a olhar em certas mesmas direções.

Mas a cidade não é algo morto a ser moldado. Ela, como produção coletiva, se esforça para nos atrair, se esforça para que olhemos em outras direções. Para isto nos propõe surpresas, aumenta a intensidade dos sons ou os torna esquisitos, muda as cores ou as torna mais fortes, muda de forma e de brilho, pisca, quebra, envelhece... Para todos os cidadãos urbanos a cidade oferece riscos de mudança.

Em um filme, qualquer um deles, há a potencialização de uma destas perspectivas de ver-entender a cidade ou parte dela, reduzindo as demais a possibilidades apenas imaginadas, enquanto aprofunda-se a escolhida. Há nisto um ganho de sentido e a criação de uma narrativa mais linear. No filme, o lugar ganha um significado mais particular, dado pelo personagem ou pelo diretor. Será o público espectador, com suas diferentes histórias de vida e imaginações, que dará novamente movimentos e perspectivas diferentes ao final da narrativa.

Em muitos momentos de Fogo e Paixão, o filme se esforça para mostrar o ambiente urbano como um conjunto de grupos distintos e separados. No terminal turístico passam pelos personagens vários pequenos grupos de pessoas: negros vestidos de roupas coloridas, americanos de bermudas brancas, jogadores de futebol, japoneses de terno e

\footnotetext{
${ }^{1} \mathrm{O}$ walk-man, além de permitir uma certa continuidade nos sons ouvidos, ele permite que eu mesmo crie uma trilha sonora para o meu dia. O filtro sonoro com o qual observo a cidade por onde ando e passo é pessoal; os sentidos que as coisas dela vão tendo são voltados para algo mais próximo ao meu desejo. Eliminando os sons urbanos - com o uso dos fones de ouvido - a cidade oferece menos riscos. O uso cada vez maior do walk-man em nossas cidades pode ser lido como a penetração da ficção do cinema na construção diária de nossas histórias pessoais.
}

(c) ETD - Educação Temática Digital , Campinas, v.9, n.1, p.341-360, dez. 2007 - ISSN: 1676-2592. 
gravata. No museu também as tribos aparecem, vendo neste ambiente apenas aquilo que mais Ihes interessa: as freiras observam um cristo crucificado, as meninas sem pescoço observam desejosas o quadro de um homem pescoçudo, os executivos fazem fila para observar um quadro e esta fila é em forma de $\mathrm{S}$ ou $\$$ e Wilma se utiliza de uma escultura para retocar o batom.

Podemos considerar o museu, o zoológico ou o terminal turístico como miniaturas da cidade, havendo neles todas as características, tanto dos objetos quanto das pessoas, que na cidade circulam. Em um momento, dentro do museu, a guia aponta uma natureza morta aos excursionistas; estes após olharem para o quadro se voltam para o lado oposto. A câmera nos mostra que a natureza morta que os personagens olham é a cidade.

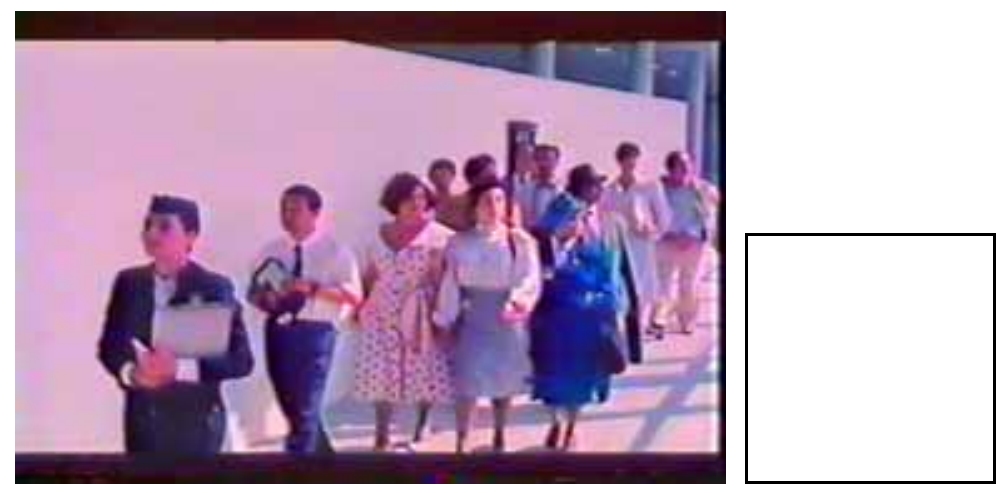

Mas se muitas tribos homogêneas e não contraditórias são mostradas no filme, a tônica principal dele são os conflitos. Não os sociais, envolvendo forças políticas opostas, mas os inter-pessoais.

A cidade é mostrada como o local do contraste e do espelhamento. Ao lado de prédios e ruas modernas param os carros antigos dos personagens, que usam, em sua maioria, roupas antigas, ultrapassadas por outras modas e estampas. Também é exemplo desta visão da cidade como local onde se juntam coisas e pessoas contraditórias o fato de se sentarem juntos o marxista e a aristocrata russa, que falam o tempo todo um com o outro em línguas diferentes. Se entendem?!!

O melhor momento em que estes contrastes urbanos estão presentes - e são mostrados como espelhamento mútuo - é na sequência do banheiro, onde a ironia nada sutil toma frente. Nesta sequência, há três diálogos intercalados. O de Wilma e Helena, o do conde com Gaspar e o cruzamento destes dois. Transcrevo-os para finalizar esta aproximação do filme e das cidades que nele se cruzam, se apresentam e se inventam.

A sequência é filmada de cima, onde se vêem os dois banheiros, masculino e feminino, separados apenas por uma parede. Eles parecem ser o espelho um do outro, dada a simetria existente entre ambos. É com esta tomada superior que se inicia e finaliza a sequência.

Durante a mesma outras tomadas, em primeiro plano ou plano médio dos quatro personagens envolvidos, intercalam-se a ela. Os três personagens envolvidos diretamente no jogo de sedução - o conde, Wilma e Helena - aparecem filmados diante do espelho, fazendo com que sejam dois numa única tomada, ampliando, e literalizando, o jogo de espelhos realizado pela simetria dos banheiros filmados de cima.

Uma vez vistas as imagens abaixo, resta aos leitores imaginar a dinâmica dos gestos enquanto lê a sequência do diálogo e pensar em que cidade este diálogo 
DOSSIÊ

\section{Área Temática: Educação Visual, Linguagens Visuais e Arte}

aconteceria. Penso que numa cidade onde além do fogo da paixão existam também a luz, a câmera e a ação: uma cidade do cinema.
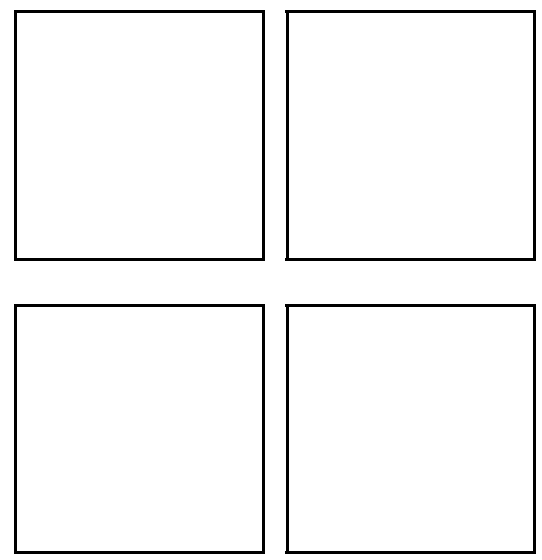

CONDE - Onde vocês vão?

HELENA E WILMA - Retocar a maquiagem.

AS DUAS AMIGAS ENTRAM NO BANHEIRO FEMININO

WILMA - Lava essa cara, Helena. Você está parecendo uma palhaça.

HELENA - Eu sou palhaça. Você me fez de palhaça. Eu estava na minha casa me refazendo...

WILMA - Pare de se fazer de vítima. Hoje você me mostrou a sua verdadeira face.

HELENA - Pára você de se fazer de psicóloga. Você é cega. Você não entende nada da vida.

O CONDE E GASPAR ENTRAM NO BANHEIRO MASCULINO

GASPAR - Na verdade, Demétrio, você é

WILMA - Entendo, entendo sim. Você me enganou direitinho, sua falsa, hipócrita. HELENA - Cala essa boca, sua egoísta.

um pouco culpado.

CONDE - Eu? Mas eu... Por quê?

GASPAR - Você sim. Com essa banca de nobre foi deixando as duas alucinadas.

CONDE - Elas praticamente se jogaram em cima de mim.

WILMA - Eu pensei que você fosse minha amiga.

HELENA - Eu fui, Wilma. Eu fui. Eu dediquei os melhores anos de minha vida a

(C) ETD - Educação Temática Digital , Campinas, v.9, n.1, p.341-360, dez. 2007 - ISSN: 1676-2592. 
DOSSIÊ

Área Temática: Educação Visual, Linguagens Visuais e Arte

você: uma monstra!

GASPAR - Diga a verdade, você primeiro WILMA - Chega. Chega de tantas mentiras. começou se engraçando com a Wilma.

CONDE - Ela é tão divertida. Eu me sinto à vontade.

GASPAR - Divertida?! Você está brincando com os sentimentos dela. Você deu esperanças e depois foi na onda da Helena.

CONDE - Helena é encantadora. Eu mal percebia que ela existia, e agora...

GASPAR - E agora?!! As duas estão na sua mão e não sabe o que fazer com elas.

CONDE - Não é bem assim. Eu não estou aqui para isto! Eu só vim me distrair.

GASPAR - Distrair? Que falta de caráter, heim? E o amor?

CONDE - Eu não quis enganar ninguém. Eu só queria conhecer outras pessoas. GASPAR - E você acha que dá prá entender estas suas intenções?

CONDE - A minha intenção foi sempre fazer o bem!

GASPAR - Eu não acredito em instinto. Sempre fui um racional.

CONDE - Mas e o amor?

GASPAR - Você é quem vai decidir.

CONDE - Eu preciso pensar.

WILMA - Amor, amor. O que é o amor? Você sabe o que é o amor?

HELENA - Se você não me atrapalhasse eu poderia saber. Você me enganou!

WILMA - Por que você não deixou claro quais eram as suas intenções desde 0 início?

HELENA - Eu não fiz por mau. Foi instinto.

HELENA - Amor não é desculpa para nada! WILMA - Eu não devo explicações. Eu vi primeiro. Ele é meu!!

HELENA - Ele é quem vai decidir.

WILMA - Antes desse passeio terminar uma de nós vai virar Cinderela.

HELENA - E a outra abóbora!

WILMA - A minha amizade me faz torcer por você. Por outro lado...

HELENA - Você gostaria que eu ficasse aqui e perdesse o ônibus.

WILMA - Seria demais Ihe pedir isto?! 


\section{Área Temática: Educação Visual, Linguagens Visuais e Arte}

CONDE - Vamos. A excursão vai continuar.

GASPAR - Desculpe se eu fui grosseiro. É

tolice. Mas, como você disse, a excursão

vai continuar. Mas uma hora ela acaba.

CONDE - E toda essa confusão foi em vão.

GASPAR - O que importa quem vai sentar

ao seu lado? O que importa é não viajar

sozinho.

SAEM OS QUATRO DOS BANHEIROS

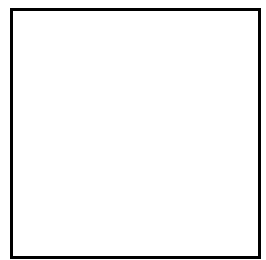




\section{REFERÊNCIAS}

ALMEIDA, M. J. Imagens e sons - a nova cultura oral. São Paulo: Cortez, 1994.

BENJAMIN, W. A obra de arte na era de sua reprodutibilidade técnica - $1^{\text {a }}$ versão. In:

Magia e técnica, arte e política - obras escolhidas. 4. ed. São Paulo: Brasiliense, 1985. v. 1.

COUCHOT, E. Da representação à simulação. In: PARENTE, A. Imagem máquina. Rio de Janeiro: Editora 34, 1993.

EISENSTEIN, S. A forma do filme. Rio de Janeiro, Jorge Zahar, 1990.

MACHADO, A. O vídeo e sua linguagem. Revista da USP - Dossiê Palavra/Imagem, São Paulo: 1993.

MACIEL, K. A última imagem. In: PARENTE, A. Imagem máquina. Rio de Janeiro: Editora 34, 1993.

MARTIN, M. A linguagem cinematográfica. São Paulo: Brasiliense, 1990.

PESSOA, F. O eu profundo e os outros eus. 5. ed. Rio de Janeiro: J.Aguilar, 1976.

TARKOVSKI, A. Esculpir o tempo. São Paulo: Martins Fontes, 1990.

XAVIER, I. Cinema: revelação e engano. In: NOVAES, A. (Org.). O olhar. São Paulo: Cia. das Letras, 1989.

FILMOGRAFIA

FOGO E PAIXÃO. Isay Weinfeld e Márcio Kogan. Brasil, 1988. 
